\title{
Biblioteka i archiwum Radziwiłłów w Białej Podlaskiej
}

()

bibliotece bialskiej wie się mniej więcej tyle ile o manufakturach Radziwiłłowej; wiadomo, że była i to znakomita, wiadomo, że Anna Radziwiłłowa była jej najważniejszym mecenasem. Śmiem twierdzić nawet, że obecnie istniejące Archiwum Radziwiłłowskie, mimo tak wielu niesprzyjających okoliczności dotrwało do naszych czasów, Annie Radziwiłłowej to przede wszystkim zawdzięcza. To ona kazała sporządzić kopie dokumentów, zadbała o solidne katalogi i pomieszczenia dla archiwum. Niemniej jednak osądy o jej bibliotece, powtarzają się prawie we wszystkich opracowaniach, są nieomal jednobrzmiące. Wszystkie te głosy w jakiś tam sposób powtarzają opinię Franciszka Radziszewskiego zawartą w dziele zatytułowanym "Wiadomości historyczno-statystyczne o znakomitych bibliotekach i archiwach publicznych i prywatnych tak niegdys bylych jako i obecnie istniejacych". ' Z pracy tej pozwolę sobie przytoczyć dłuższy cytat: "Biała 2/ Biblioteka książąt Radziwiłłów, znajdująca się na zamku, znacznie pomnożona przez księżną Annę z Wiśniowieckich [!] $]^{2}$ Radziwiłłowa, ok. 1750 r. [!] przewieziona do Nieświeża". "Nieśwież" Biblioteka ta powstała jeszcze za czasów kardynała Jerzego Radziwiłła [...] Później Anna z książąt Sanguszków Radziwiłłowa, przyłączywszy do niej znaczną swoją bibliotekę przechowywaną w Białej na Podlasiu ${ }^{4}$, co rok za kilkaset czerwonych złotych nowe większe dzieła kupowała. Ten oddział zwał się biblioteką bialską. Księżna Urszula z Wiśniowieckich Radziwiłłowa [...] lubiąca literaturę,starała się także o pomnożenie tutejszej biblioteki, zawierającej już wtenczas 9000 tomów. ${ }^{5}$ Wreszcie jeden z późniejszych Radziwiłłów nabył droga transakcji [!] bibliotekę po marszałku polnym hr. Flemingu. ${ }^{6}$ Ten oddział zwał się biblioteką flemingowską. Tym sposobem uformowała się biblioteka ordynacka. Zawierała ona w 1750r. przeszło 14000 tomów, w tej liczbie prawie 3000 dubletów i 200 potrójnych egzemplarzy. Machnicki był jej pierwszym [!] i podobno ostatnim bibliotekarzem [...] Rękopismów dość było w tej bibliotece, między niemi zasługiwały na uwage "Acta Tomiciana" w 17 
tomach in folio oraz Inventaire général de toute la France, 8 tomów in folio. $\mathrm{Za}$ wydanie tego ostatniego, miano ukarać szubienica sekretarza królewskiego. Biblioteka ta ok. 1770 zawierała do 20000 tomów. Składała się z dzieł po większej części francuskich; łacińskich było niewiele a polskich jeszcze mniej. Wydań do roku 1650 nie było. W 1772 przewieziono te zbiory do Petersburga i po większej części wcielono do Biblioteki Akademii Nauk [...] Archiwum Radziwiłłowskie w Nieświeżu było najważniejszem i najbogatszem z wszystkich archiwów prywatnych w całej Polsce. Mikołaj Radziwiłł, Marszałek i Kanclerz Wielki Litewski otrzymał w r. 1551 przywilej wylączny na zachowanie w archiwum zamku nieświeskiego wszystkich przewilejów [!], nadań, praw i prerogatyw, tak w ogólności dla prowincyi W. Ks. Litewskiego, jako i w szczególności dla obywateli służących. Następnie zaś każdego panowania Radziwiłłowie wyrabiali sobie tego przywileju potwierdzenie. Tym sposobem utworzyło się ogromne archium Radziwiłłowskie w Nieświżu gdzie i obecnie zajmuje jeszcze kilka sal w zamku. Między inemi rzeczami znajdowało się tam 400 voluminów rodzinnych dokumentów, przywilejów i autografów; autograf zjednoczenia Litwy z Polska, podpisany przez króla Zygmunta Augusta i wszystkich senatorów. Ostatniemi czasy wiele rzeczy $z$ archiwum rozeszło się $w$ rozmaite ręce, $n p$. wiele przeszło do Kajetana Kwiatkowskiego [bibliotekarza $\mathrm{i}$ archiwisty, który za sprzedaż dokumentów i cennych książek, m.in. do Kórnika, miał wytoczony proces] a później dostało się do zbiorów Kórnickich hr. T. Działyńskiego, np. "Tomiciany" [...] Jakie jest to bogactowo tego archiwum, wnieść można stąd, że dokonany przez Symonowicza spis dokumentów części Wittgensteinowskiej, zajął 6 tom. in folio. Dokumenta te sa już uporządkowane i dotycza 8359 rodzin, a na liczbę wynosza więcej 300000 sztuk. Część Radziwiłłowska także ma już być uporządkowana. Są to dokumenta odnoszące się do rodziny Radziwiłłów, mieszczą się one w 396 tekach, w kazdej po 500 sztuk. Tek obejmujących pisma własnoręczne tej familii i do nich osobiście adresowanych jest 37 [...] Kolosalna to praca, bo dokumentów wszystkich ma być 589806 sztuk."

Pewne wiadomości należałoby sprostować. Otóż, przez porównanie katalogu części zbioru znajdującego się w Nieświeżu z katalogami Anny Radziwiłłowej wynika, że tzw. biblioteka i archiwum bialskie zawierały jeżeli nie całość - to z pewnością część zbiorów nieświeskich. W bibliotece podręcznej Anny Radziwiłłowej znajdowała się np. genealogia domu 
Szydłowieckich, stary, na pergaminie spisany zabytek, który z pewnością pochodził ze starego zasobu. Biblioteka i archiwum (jak wynika $\mathrm{z}$ warunków ordynacji) nie były podzielone. Stąd też można mniemać, że Biblioteka Radziwiłłowej mogła obejmować całość zbiorów Radziwiłłowskich. Z drugiej jednak strony wyminięcie takich warunków nie stanowiłoby dla tej niewątpliwej bibliofilki żadnych trudności. Pierwszy katalog ksiażek Radziwiłłowej pochodzi z 1720 roku, ${ }^{8}$ a zatem spisany był po śmierci jej męża. Z wcześniejszych czasów pochodzą dwa katalogi: "Katalog ksiag w Nieświeżu" "Catalogus librorum arcis Nesvisiensis A. Domini 171329 novembris conscriptorum" z pomieszczonym przy nim "Regester Bibliotheky Nieświskiej Xiag złożonych w szafie po lewej ręce" (bardzo niestarannie zrobiony) ${ }^{9}$. Zapewne powstał on na zamówienie Radziwiłłów, w tym samym czasie (1713 r.), w którym J.W.Tauczyłowicz $^{10}$ ekspediował wszystkie księgi "arcis Bałensis": "Księgi wszystkie, które maią inskrypcią Arcis Bałensis przebrawszy y zregestrowawszy oraz y obrazy J.C.X.X.J. w Zamku Nieświeskim przed ruiną szwedzką novo malowanych № 22 odsyłam (...) bibułą przekładane aby się nie potarly na wałkach." Zatem oboje kanclerstwo bądź to sprowadzili księgi przywiezione do Nieświeża przed wojną północna, bądź to (co mniej chyba prawdopodobne - bo lubili czytać oboje), dopiero w 1713 roku zdecdowali rozdzielić bibliotekę ordynacką na dwie części: Bialską i Nieświeską. Przy tej okazji powstały dwa regestry, z których zachował się tylko "Catalogus librorum arcis Nesvisiensis". "Przypuszczać można, że po śmierci męża Radziwiłłowa sprowadziłą do Białej z Nieświeża, w którym przebywała dość rzadko, jeżeli nie wszystkie - to przynajmniej najcenniejsze książki i archiwa. Katalog Radziwiłłowej z 1720 r. opatrzony został tytułem: "Katalog książek Madame Radziwiłł" (napis na okładce) Des livres de la Bibliotheque de Son Altesse Madame la Princesse de Radziwiłł. Enregistrez de ranger dans les Armoires pren des Fenetres de ses appartemens, l'année 1720 (tytuł wewnattrz) Catalogue des livres de la Bibliotheque de Son Altesse $S^{\text {me }}$ Madame la Duchesse de Radziwiłł enregistrez selon d'ordre des Tablettes des Armoires. Les lettres de la premiere colonne de chaque page montrent les armoires dont il'y a autant que lettres dans l'alphabet et chifres de la seconde montrent les Tablettes ceux de la troisieme marquent le numero, qui est aussi marque audedans. Ce catalogue sert atrouver tout d'un coup un compte trés - exact de tous des livres. Faut seulement (enfaisant la revue) prendre garde, si le 
nombre des livres de chaque Tablettes repond a l'addition des ecriteaux, qui y sont attachez ou bien a celle du present catalogue 1720 .

Sommaire de toute la Bibliotheque.

Livres sacres et spirituels, livres devotion et de prieres, sermons et meditations en langue francoise, voyez les Armoires A C E F G

Livres de devotion enlangue Polonaise $\quad H$

Les Voyages

Livres sur toute sorte de sujets

Les Lettres vers la fin de la meme lettre

$\mathrm{H}$

K

$\mathrm{K}$

Livres de geographie, de Peinture, de Fortifications, de Architecture, de perspectives, des Vues, d' estampes de desseins, de palais, de plans de jardins avec les grands dictionnaires in folio $\mathrm{M}$ Livres instruction dans les sciences $\mathrm{N}$ Livres de Morale $P$ Histoires

Memoires voyez encore

$\mathrm{R}$ et $\mathrm{T}$ $\mathrm{T}$

Romans

Livres in $4^{\text {to }}$ sur toute sortes de sujets voyez les lettres

Jak wynika tylko z przytoczonego tytułu, zbiór biblioteczny mieścił się w apartamentach księżnej. Ów podział uwzględniający zarówno tematykę jak i formaty książek jest zachowany także $w$ późniejszym, bo pochodzącym z 1731 roku katalogu, który, jako pełniejszy, przedstawiony jest $\mathrm{w}$ aneksie mojej pracy (masz.). Z całą pewnością uwzględniono w nim pozycje pochodzące $\mathrm{z}$ katalogu z 1720 roku.

\section{BIBLIOTEKA ŁACINSKA}

Z roku 1733 pochodzi "Catalogue des livres latins et Polonois de la Grande Bibliotheque de son Altesse Serenissime Madame la Duchesse Radziwiłł Grande Chancelliere de Lithuanie, ou se trouvent dans huit grands armoires de son Tresor marques par ces Lettres A B C D E F G H ect. [AR, rkpsy bibl. I - 9] Dont les quaires premiers contiennent les livres in folio. Les autres quatre ceux in quarto at in octavo. Tous enregistrez l'annsée 1733 selon f'ordre de la matiere dont ils traittent. On a observe 
quatre choses en faisant le catalogue: scavoir a mettre.

I. Le Titre ou le sujet de chaque livre.

II. Le Nom de son Auteur.

III. L'Année qu'il a étè imprime pour scavoir s'il est vieux ou nouveau.

IV.Et enfin aussi l'endroit de son Impression pour l'avoir s'il manquoit

A La FIN Se trouve la petite Bibliotheque particuliere de Son Altesse, composée, de toute sorte de beaux Livres de Prieres et d'autres en Polonais O.A.M.D.G."

W zbiorze tym Radziwiłłowa umieściłą piśmiennictwo łacińskie, włoskie, polskie, francuskie. Sądząc po datach wydań i porównując ów spis z katalogiem z roku 1713 (obejmującym zbiory nieświeskie) stwierdzić trzeba, że najprawdopodobniej większość zbioru stanowiły stary zasób; choć widać i późniejsze zakupy. Jest to zbiór, w odróżnieniu od biblioteki francuskiej (tzw. Podręcznej) dość nierówny. Obok znakomitych dziel, interesującego zasobu literatury innowierczej, prawniczej, klasycznej literatury i filozofii wiele jest dość przypadkowych. Katalog ten wymagałby szczegółowego obiaśnienia, na które brak w pracy miejsca. Ważniejsza dla charakterystyki osoby samego mecenasa jest analiza, zakupionej przez Radziwiłłową i jej męża, biblioteki francuskiej. Niemniej jednak, zawierajacy 1041 tytułów zbiór książek i manuskryptów wymaga częściowego chociażby omówienia.

Mimo wzmianki, że obejmuje litery do G ect., na tejże literze się kończy.

Pod litera A znajdują się 4 numery: w numerze pierwszym pomieszczono dwa tesaurusy: "Thesaurus antiquitatum romanarum"

i "Thesaurus (jraecum Antiquilatum" - obydwa w 12 tomach. Numery 2 i 3 to "Biblia et commentari in Scripturam Sacram" zawierający między innymi: "(ommentaria posthuma in plerosque Novi Testamenti lihros" Jonasza Szlichtynga (wyd. z 1656 roku) ${ }^{12}$. W numerze czwartym umieszczono pisma Ojców i doktorów kościoła. Tę samą tematykę zawiera dział B nry 1 do 2, przy czym już od drugiego rozpoczynają się pisma związane w ogóle z kultem czy też kościołem. Wśród nich wyróżnić możemy "Jerosolymitiana Peregrinatio Ill. Princ. Nicolai ('hristophori Radivily" wydane w Antwerpii w 1614 roku, ${ }^{13}$ czy też "Opera omnia" J. Wolzogena wydane jako 8 tom "Bibl. Fratrum Polınorum..." a także dzieła Erazma z Rotterdamu.

Pod literą C objęto: (Numero 1) Politica, Ascetica, Symbolica, Heraldica, pod nrem 2: atlasy, dzieje świata i studia geograficzne - 
tu znalazło się miejsce dla dzieł Andreasa Cellariusa czy J. Kepplera. Nr 3 zawierał: Annales, Kroniki, Chronographica et Cosmica - a w numerze 4 - wiadomości z medycyny, historii, wojskowości.

Jednym z najbogatszych działów biblioteki wielkiej - był dział D "Continuatio historiarum, thesaurus linguarum, annales Polonicae, Constitutiones, Leges, Statuta Poloniae". Konstytucje, prawa i statuty polskie obejmowały całość piśmiennictwa. Wśród znaczniejszych prac historyków warto wymienić: M. Stryjkowskiego (rękopis ,na podstawie którego zresztą wydano "O poczatkach, wywodach, dzielnościach (...) narodu litewskiego" w Warszawie w 1978 r.). Sama zreszta Radziwiłłowa musiała znać ten rękopis, skoro na k. $5^{14}$ własnoręcznie napisała notatkę: "N 32 z biblioteki naszej AXR"; Jana Długosza, dwa "Klimaktery" Wespazjana Kochowskiego 15 , J.I.Petrycego: ${ }^{16}$ "Historia rerum gestarum in Polonia" z 1620 roku (Kraków), St. Sarnickiego "Annales sive de origine et rebus gest is" z 1587 roku, ${ }^{17}$ "( hronica gestorum in Luropa" Pawła Piaseckiego (Kr. 1645) ${ }^{18}$ czy K.Warszewickiego (N.K. nie notuje) "C.C.Caesarum Regum el Principum unius et ejusdem partim generis..." wydane w Krakowie w 1603 roku. Tyle, żeby wymienić polskich twórców - bo przecież nie brakowało klasyki światowej: S.Pufendorfa "De rebus gest is Friderici Wilhelmi Magni" (Berlin 1695) czy też dzieł C. Tacyta i Velleiusa Paterculusa w opracowaniu Lipsiusa a także Seneki czy Cicerona. Znalazła się tu także cała "Biblioteca fratrum Polonorum, quos Unitarios vocant, instructa omnibus Fausti Socini et Joan. Crelly [...] Irenopoli 1656". Jeśli przyjąć, że są to książki ze starego zasobu - to kto wie, czy nie miał racji Dürr - Durski nazywając Katarzynę Sobieską kryptoarianką? Nawet jak na bibliotekę, w której pomieszcza się prawie wszystkie ważniejsze teksty innowiercze, czy też odzwierciedlające dyskusje światopogladowe w Europie, to w Bibliotece lacińskiej i tak druków ariańskich jest mnóstwo. W bibliotece francuskiej - a więc we właściwej bibliotece Anny z Sanguszków Radziwiłłowej nie ma prawie arian - za to prawie komplet francuskich druków jansenistycznych - a zatem nie był to księgozbiór dobierany przez ks. kancelarzynę.

W numerze "4 D" zatytułowanym: "Libri varii, inter etiam de Polonia tractantes" wymienia się "Poczet herbów salachty Korony Polskiej y WXL przez Wactawa z Potoki Potockiego" (Kr. 1696), ${ }^{19}$ "Zielnik" Szymona Syreniusza z $1613 r,{ }^{2 \triangleleft}$ "Monumenta Sarmatorum" Szymona Starowolskiego $^{21}$ (Kr. 1655). W dziale tym mieszczą się także tłumaczenia, np. 
przez Sebastiana Petrycego "Etyki" i "Polityki" Arystotelesa, ${ }^{22}$ przez Wojciecha St. Chróścińskiego "Pharsalii" Lukana ${ }^{23}$. Ow stopien "traktowania o Polsce" jest dość różny bo znajdują się tam i pisma Jerzego Lubomirskiego, i napisany przez Frydrychowicza "Zywot,Jacka Odrowaza" obok słownika łacińsko-polskiego Jana Mączyńskiego ${ }^{24}$ (z 1564 roku).

W numerze 5: "Historiae, concion'es, orationes, panegyres" - nie odnotowano ciekawszej pozycji.

W numerze następnym panuje także podobne pomieszanie, bowiem określono jego zawartość jako: "libri latini (od nru 3 także Polonicae) sacri spirituales et chronologici". Stąd też najwięcej w tym numerze rzeczy najmniej wartościowych jak choćby owe: Stefana Żuchowskiego "Odglos procesów criminalnych na Żydach" z 1700 r. czy też "Carownica l'owolska". Wydaje się, że ta część zbioru nie jest tak wyraźnie sprofilowana jak pozostałe. Niemiej jednak znajduje się w nim dość sporo interesujących tekstów: np. "Repertorum opuscula latina sacra et moralia", wydane w Warszawie w 1701 r. "Wiersze y insze pisma" ks. Stanisława Grochowskiego $^{25}$ z 1607 roku, pisma Filipa Kallimacha, Andrzeja Maksymiliana Fredry, Gwagnina, Hartknochta, M.K.Starowolskiego, Mikołaja Chwalkowskiego "Pamięınik albo kronika ziem pruskich", "Historya Inflandzka y Kurland" wyd. 1 w Poznaniu w 1712 roku, pisma Górnickiego: "Dzieje w Koronie Polskiej" z 1637 roku i "Dworzanin" z 1639 roku, a także "(ommentariorum ('hotiniensis beli" Jakuba Sobieskiego. W dziale tym występuje sporo dzieł poetów polskich, pamiętnikarzy historyków a także tłumaczeń. Bowiem, oprócz. wymienionych znajdujemy Samuela Twardowskiego "Miscellanèà selecta", wydane w Kaliszu w 1681 roku i tegoż "Szcześliwa Mosklewska expedycyę" z 1634 r., "Historię Polski" Kadłubka w tłumaczeniu Jana Alana Bardzinskiego w Toruniu w 1694 r., tłumaczenie Boecjusza zatytułowane "Skuteczny to jest pociecha Filozofiey, niegdy od Anicjusza Manliusza Torquata Seweryna Boecyusza napisana". Tu swoje miejsce znalazły także: "Zwierciadlo" W. Korwina, "Zwierciadlo ró̇ne na trzy częíci rozdzielone przez Szczęsnego Zebrowskiego" (Kr. 1653), "Stolecznego mias/a Krakowa abo kościoly $v$ co w nich jest widzenia godnego przez P'iotra Hiacyntha Pruscza, Kraków 1650", czy też "P'owinności zycia domowego gospodarskie napisane po francusku w Brungzbarku, extans w Warszawie w 1716 r".

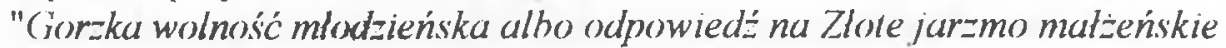
przez jednq Damę Dworskq", czy też Stanisława Morsztyna "Smutne żale 
po utraconych dzieciach w roku od narodzenia pańskiego 1698 napisane".

Przytoczone tu tytuły dzieł poświadczaja, że spis był robiony niezwykle porządnie i najpewniej $\mathrm{z}$ autopsji - rzadko kiedy zdarzają się nieścisłości w zapisie, prawie nigdy zmiana daty wydania.

Jeszcze jedna uwaga nasuwa się przy tej okazji. Numer następny (6 i 7) przedstawia literaturę medyczną, chemiczną oraz dział "Poetae". I tu, oprócz Sarbiewskiego, Bieżanowskiego mamy klasyków: Prudencjusz, Homer, Horacy, Naso, Fedrus, Catullus, Juvenalis, Martialis, G.Buchman, Grotius - bądź to reprezentowani w samodzielnych tomikach, bądź to w licznych bardzo antologiach, wyborach ect. Otóż wydaje się, że ów zapis katalogowy odzwierciedla ówczesne rozumienie terminu poeta i poezja, czy też przedstawia i dokumentuje zawężenie takiegoż li tylko do twórców antycznych (przynajmniej przez twórców katalogu). Polscy poeci znajdują się w działach innych "Librorum de Polonia" - czy nie jest to skutkiem pojmowania $\mathrm{i}$ unoszenia się poezji $\mathrm{w}$ szkołach na najdoskonalszych przykładach łacińskich?

Pod literą F umieszczono głównie: libri historici, de bello et pace de statu et Republica et politici do połowy numeru 5. W nim zawarte dzieła Tacyta, Liwiusza, Swetoniusza, Salustiusza, Plutarcha. Oprócz dzieł klasycznych pojawiły się także prace bardziej współczesne: Machiavellego, H.Cardana: "Arcana politica sive de prudentia civili" Lipsk (1673), pisma Krzysztofa Warszewskiego czy też "Propositiones (Christiano - politicae unitati et pietati animorum" Krzysztofa Stanisława Zawiszy ${ }^{26}$ (Kraków 1695). W numerze 6 zawarte były "Orationes", "Harangues", w numerze 7 "Orationes Epistole", gdzie, oczywiście pomieszczono pisma Cicerona a także J.Lipsiusa, Pliniusza Coeciliusa, Symmacha Aureliusza. W numerze 8, który kończy literę F "Libri Rhetoricem seu eloquentiam docentes", w poddziale: "Pro scholis inferioribus" odnajdujemy prace J.Pontanusa i dwie książki J.A.Komensky'ego: "Janua aurea quinque linguarum reservata" (Frankfurt 1644) i jeden z najgłośniejszych jego podręczników nauczania poglądowego: "Orbis sensualium pictus et hoc omnium fundamentum in mundo rerum...", wydany w Norymberdze w 1714 r.

W numerze $G$ odnajdujemy także dość sporo ciekawych książek, już to w numerze 1 "Philosophi" - gdzie zebrano prace: Arystotelesa, Franciszka z Toledo, Kartezjusza, Cicerona, G.Schotta, E.Agryppy, Seneki, Lipsiusza czy też Alberta Wielkiego, już to w nrze 2 "Libri mathematici, arithmetici, architectonici et variarum aliar. scientiarum", gdzie znajdowała się m.in. 
"Kosmografia" Pomponiusza Melli. Następne numery do 5 obejmują "libri Italici, gallici, livres espagnols et portugais". I jeszcze w numerze 5 rozpoczyna się spis manuskryptów, obejmujących w numerze 6 "livres qui concernent l'eloquence ou la Rhetorique", nr 7 Libri sacri - manuscripta, historici - manuscripta. Wśród ciekawszych tekstów z tego zbioru można wymienić: "Ad virum nobilem de cultu Confucy philospophi et progenitorum apud Sinas, Leodÿ 1700", dużo literatury włoskiej (choć dobór jej niezwykle przypadkowego robi wrażenie): "La comedia de Dante Aligieri con la nova espositione di Alessandro Vollutelo" z 1544 roku, Antonio Possevino: "Il soldato christiano con nove aggizmte" Venetia 1604, Guarini Battista: "Il Pastor fide. Tragi - comedia", Venetia 1621, "Il figlio della solve Dramma per musica, composto da Carlo Sigismondo Capece", Roma 1687, "Latona in Delo divertimente teatrale da representarsi nel Regio Theatro di Varsavia ann. 1699 et posto in musica dal Sig. Gio. ('hristoforo Schmitt, Direttore di Capella de Sua Majesta eto. in Varsavia", "La Rosmina overo amor unol'i Giusto Scherso Rusticale ect. Varsavia", "Marte e Amore. Drama da representarsi in Musica ect. opere di D. Michel Angelo Bruneria ect. Capellano della Regina", "La Sofonia poematto oratoria in Roma 1687", "Recole sul Tarmodonte drama per Musica in Venetia, Satire di Salvator Rosa declicats a settabo, in Amsterdam", "La rete di Vulcano, in Venetia 1640", "Il Galateo overio avisi di buone Creanze di Ciovanni della Casa, in Roma 1685".

Istnienie tego włoskiego zbiorku, szczególnie poświęconego teatraliom raczej potwierdza sformułowaną wcześniej uwagę, że tzw. Wielka biblioteka łacińska była uformowana ze starego zasobu i istniała jakby poza zainteresowaniem czytelniczym Anny Radziwiłłowej. Zbiorek ów, na podstawie prac A.Sajakowskiego dotyczących historii stosunków polskowłoskich i mecenatu Radziwiłłów należałoby raczej wiazać z postaciami Michała Kazimierza Radziwiłła i jego syna Karola Stanisława. W manuskryptach poetyckich znajdujemy wyciagi z literatury polskiej, czasem nawet ze zbiorów drukowanych jako owe "Poemata nonnula poetarum Polonorum ex impressis libris excerpta" - nie były to chyba rewelacyjne rękopisy, jak w przypadku dzieł historycznych.

W numerze 6 , który miał być poświęcony elokwencji albo retoryce, oprócz dziel Cicerona, manuskryptu "Orator Polonus", odnajdujemy także "libri philosophici", a wśród nich: "Cursus Philosophicus" Marcina Radymińskiego, Andrzeja Kucharskiego: "In primam partem philosophici", 
Mikołaja Mościańskiego: "In logicem"; jest to godny uwagi przypadek zgromadzenia stosunkowo dużej ilości polskich pism filozoficznych (lub choćby wykładów). Oprócz tej innowacji, przeważa Arystoteles w tłumaczeniach łacińskich $z$ komentarzami. W numerze tym miejsce znalazły również manuskrypty medyczne. W numerze 7 pomieszczono manuskrypty "libri sacri", historyczne, i tu: "Rellacya poselstwa do Turek posla oświeconego Xcia Krzysztofa Zharaskie(go)" Teodora Zawadzkiego, "Catalogus Ducum atque Regum Polonorum", "Historia o Rewolucyi Krolestwa Swedzkiego y Dunskiego po polsku wylożona". Resztę zajmują "Publica - Manuscripta", w których znajdowały się listy oryginalne i kopie, traktaty polityczne, manuskrypty o różnej tematyce, katalogi.

Całość kończył spis "Livres, qui n'ayant jamais étè enregistrez ont étè ajoute à cette Bibliotheque. Ils sont tirez des Archives et se trouvent maintenant sous la lettre D numero 5 tout en bas a la fin". Tu wymienia sie między innymi, "Kazania na Niedziele y Święta calego roku" X. Piotra Skargi (Kr. 1597). a także "Kazania przygodne z inemi drobnieyszemi pracami o Roznych rzeczach wszelakim stanom nalezacych" X. Piotra Skargi (Kr. 1610), a także "Apologia pro Ill. ac Cell. Prin. Janussio Duce Radzivilio".

Katalogi znajdujące się $w$ archiwum radziwiłłowskim dotyczą stanu biblioteki do ok. 1734 roku. Wiemy z całą pewnością, że pomimo wcześniejszego podziału biblioteki z 1735 roku, ${ }^{27}$ biblioteka znajdowała się w całości w Białej jeszcze w 1741 roku. Radziwiłłowa tak pisała do syna, Michała Kazimierza: ${ }^{28}$ "Rozkaż, Moie Dziecie, w Bibliotece swoiey uczynić miejsce na Bibliothekę Francuską, którą wkrótce stąd dla ciebie wybrawszy poszlę, chcąc, żebyście między sobą, Moie Dzieci po śmierci moiey, żadney nie mieli kłótni..." Radziwiłłowa do tego czasu zmodernizowała pomieszczenia dla książek. Otóż jak dowiadujemy się z listu Deshomme'a ${ }^{29}$ z 1737 r.: "Biblioteka WXMD skończona ze wszystkim, tylko czekam, póki P.Porucznik [Goffaux] Xięgi ułożył, żeby ja mógł kazać woskować". O budynku biblioteki (plan budynku w aneksie) pisał także E.Łopaciński, ${ }^{30}$ sugerując, że składa się $\mathrm{z}$ trzech pokoi na parterze i jednego w nadbudówce. W Archiwum Radziwiłłowskim ${ }^{31}$ znajdują się projekty szaf bibliotecznych, robionych na zamówienie Ks. Kanclerzyny. Projektowano ich wielkość, np. "głembokość szaf na miarę fascykułu".

Przed przebudową i przeniesieniem biblioteki i archiwum Radziwiłłowa przeprowadziła "ogromną" inwentaryzację, którą głównie objęto, jak się 
wydaje, archiwa. Inwentaryzacja była przeprowadzona prawdopodobnie w oparciu o posiadane katalogi książek, gdyż rejestry spisowe $z$ tego okresu obejmują tylko dokumenty znajdujące się w jej archiwum. Katalogi książek mogły jednak zaginąć. Zachowane z tej inwentaryzacji to np.: "rejestr spraw ordynackich"32 czy też "Regestr dokumentów authenticznych y różnych Papierów regulujących się do komędy Poznanskiey Kawalerów maltańskich sporządzonych przy rewizyi w Białey men. 8bris 1736 r." ${ }^{33}$

Oczywiście spisy dokumentów istniały wcześniej jak np. "Regestr spraw ordynackich z 1724 roku", ${ }^{44}$ jednakże właśnie ok. 1736 r. zostało uporządkowane całe archiwum, o czym dowiadujemy się z korespondencji porucznika Goffaux, Africanus Honorius Goffaux inżynier i archiwista bialski pełnił, jak to zwykle w owym czasie, kilka funkcji. Zajmował się m.in. budową placów, kanałów, projektował młyny ${ }^{35}$ - jednakże jego właśnie dziełem, wraz z zespołem kopistów, była inwentaryzacja tego przeogromnego archiwum. Inwentaryzacja, dodajmy, połączona $z$ kopiowaniem części dokumentów dla Nieświeża. Zlecając kopiowanie części dokumentów Radziwiłłowa kierowała się zapewnie chęcią wyposażenia obu synów w kompletne archiwa rodzinne (jak wiemy, w latach 1730-1740, duża część dokumentów znajdowała się równolegle w Białej i w Nieświeżu). Radziwiłłowa miała zapewne na względzie utworzenie archiwum dla ogromnych majętności Hieronima Floriana i jego ewentualnego potomstwa. A.Goffeaux ${ }^{36}$ donosi w 1736 roku: "Je suis occuppe a faire mon Registre alphabetique pour papiers de Białła; Les ecrivains travaillent aux registres en double, tant ceux qui doivent rester a Białła, que ceux doivent etre envoyes a Nieswiz".

Prace przy inwentaryzacji trwały dość długo, przeciagnęły się aż do 1737 roku (wtedy też ukończono budowę oddzielnego gmachu dla biblioteki): "Les écrivains continuent a écrire les Registres en double des Papiers de Białła et d'abord, qu'ils auront a chêves nous arrengerons les Papiers de Słuck; en outre, comme j'ay deja en I'honneur de marquer a VAS par ma precedenta du 21 Xbre passe. Jasiński a étè péndant deux somaines a Mieleyczyce avec $\mathrm{M}^{\mathrm{r}}$ Le Capitaine pour les comptes, et y a encore étè occuppe icÿ; Szawulkiewicz a ecrit en double le podania hrabstwa białski a 1736, l'un pour archive, et l'autre pour l'administrateur; - Lukaszewicz les comptes de Kiowiec, Zasztramowicz le registre de toute, les lettres, tant celles qui sont allees a Nieswiz, que celles, qui sont restees icy. Et les samedis et dimanches ecrit les ordonnances chex l'administrateur, comme 
aussÿ les depeches que $\mathrm{M}^{\mathrm{r}}$ Le Capitaine expedië à VAS. Moÿ j'aÿ arrenge les papiers de Białła en ordre dans les petites armoires du cabinet ou garderobe joignant la salle des Archives; j'ay fait le dessein et description pour le moulin a battre le grain et hacher la Paille, comme aussÿ un autre pour elever". ${ }^{37}$

Z podanego fragmentu możemy odczytać ponadto nazwiska archiwistów (kopistów) Radziwiłłowej. Kancelarię, założyła wcześniej, ${ }^{38}$ jednakże wymienieni kopiści mogli też pracować li-tylko na potrzeby archiwum. Z zachowanych rękopisów pochodzacych z Archiwum Radziwiłłowskiego widać, że większość - to osiemnastowieczne kopie. Część z nich powstała jako wspomniane już wyżej odpisy dla synów - tym bardziej, że Pani na Białej niechętnie pozbywała się oryginałów: ${ }^{39}$ "Dyariusz SP. Xcia Imci Kanclerza [najprawdopodobniej chodzi tu o Karola Stanisława] ręką Imci Pana Złotkowskiego pisanego in originali Xiężna Jeymość nie posyła, ale do przepisania dla Waszey Xcey Mości Dobrodzieya kazała mnie go dać (...) Listy zaś wszystkie WXMD z cudzych kraiów (...) in originali, znalazłszy w Bibliothece odesłać ma."

Radziwiłłowa dbała o kształt archiwum nie tylko poprzez porzadkowanie i uzupełnianie, lecz także rekuperację archiwów (nie wspominając o tym, że jakikolwiek zajazd majętności wykradaniem archiwów się kończył). Najważniejszym jej sukcesem w tej dziedzinie było odkupienie archiwów do dóbr neuburskich (po Bogusławie Radziwille). Pertraktacje zaczęły się dosyć wcześnie, już prawdopodobnie w latach trzydziestych. Prowadziło je wielu plenipotentów i doradców (m.in. G.H.Hoffman, rezydent pruski ${ }^{40 .}$, spadkobierca $^{41}$ Fryderyk Wilhelm Adams dość długo zwodził ks. Kanclerzynę. Dwór berliński prowadził przez swego rezydenta Hoffmana dwulicowa grę. Dopiero jej kasjer, Szmujło Ickowicz w 1741 roku doprowadził do zawarcia transakcji ${ }^{42}$ Stąd też mogłą napisać w liście do syna: ${ }^{43}$ "Ja tu, z łaski Boskiey, kończę interes niesłychanie wielki, to iest rekuperacyą archiwów waszych Radziwiłłowskich, która mię kosztuje na dwadzieścia tysięcy złotych dobrey monety y ośm".

Zakupów do biblioteki Radziwiłłowa dokonywała poprzez podróżujących synów, kupców a także poprzez bezpośrednie zamówienia w księgarniach. Szczęśliwym zbiegiem okoliczności zachował się list Radziwiłłowej, w którym poleca ona Goffeaux. ${ }^{44}$ "Rejestru ksiąg, które z Amsterdamu - poszukać i zapieczętowawszy w list odesłać do Amsterdamu à M.Chatelain Libraire adresując ten list". Może to zbyt daleko idący 
wniosek, lecz list ten jest jak gdyby zamówieniem według "zapowiedzi czy też dysponendy" wydawnictwa. Zachowała się także kopia (być może tego właśnie zamówienia), któą warto chyba przytoczyć in extense: ${ }^{45}$ "Memoires des livres domande's au S.Chatelain à Amsterdam. Avantures de Télèmaque, fol. refie; Histoire de Theu $4^{0} 16$ vol. refie; Bibliotheque Orientale - le plus nouvelle; Le Dictionaire de Moreire avec le suplement. Veritable.

Calendrier chronologique et historique pour l'année 1737 contenant la connoissance des Tems, et autres mouvements celestes. Ensamble une suite chronologique des Evenemens les plus curieux les conseils du Roÿ, un Etat des Cardineaux avec la naissance et mort des Roys, Reines, Princes et Princesses de l'Europe, enrichies de Remarques. Historiques et aussi plusieur autres defferentes nouvelles, detailles dans la Table alphabetique jointandit calendrier dedie a Monseig' Le Duc d'Orleans premier Prince du Sange.

\section{À Paris}

De l'Inprimierie de Gissż̈, ruë de la vielle Boucheria, à l'arbre d'Jesse avec aprobation et Privilege du Roÿ.

Le Calendrier de Lafour, tire des Ephemerides contenent le Lieu ce lever et le coucher du soleil et de la Lune etc.

Pour l'année 1737 avec la naissance des Roys, Reines, Princes et Imprime (brak) a la Famille Royale et Maison de Sa Majestate à Paris L'Imprimerie de Jacques Collombat. Imprimeur ordinaire du Roy et ruë de $S^{\prime}$ Jacques au Pelican avec Privilege du Roy. Entrennes Mignones curieuses et utiles pour l'année 1737 avec privilege a Paris (...) J.T.Jouenne, Rue St. Jacque a St. Landry."

Książki przysyłali jej także korespondenci tacy jak, np. F.Accoramboni w latach 1721-1743. Bardzo ciekawym przykładem współpracy bibliofilów jest rachunek z 1735 roku ${ }^{46}$ opiewający na sumę "guldenów holęderskich 783 sztyb 10" a wystawony Annie Radziwiłłowej przez Pana Białłozora (Mateusz?). Otóż zakupił on dla Księżnej i siebie "farfury, ozoby hińskie, pistolety" a także książki według podanej w przypisie listy. Które z nich zakupiła Księżna?

Wspomniano już o tym, że duża część zbioru w bibliotece Radziwiłłowej mogła być kupiona przez wcześniejszych właścicieli. Niemniej jednak, trudno tę sprawę rozstrzygnąć jednoznacznie, kierując się np. datami wydań. Bo oto w katalogu (patrz aneks) biblioteki francuskiej (poz. LXVIII 
- 26) należąca do "Livres nouveaux" książka Bertranda Moreau: "Recueil curieux" została wydana w 1696 roku. Zatem wcześniej wydane mogły być kupowane przez ks. Kanclerzynę. Nie tyle ważne jest bowiem datowanie zakupu ksiażki ile fakt umieszczenia ich w bibliotece podręczenj.

Wszyscy badacze tematyki bibliofilskiej zaliczają radziwiłłowskie zbiory książek do najwartościowszych w Koronie i Litwie (szczególnie archiwum). Bez watpienia porównanie księgozbioru Radziwiłłów z dopełniającym się już podówczas zasobem braci Załuskich wypadnie zdecydowanie na niekorzyść Radziwiłłów (przynajmniej liczbowo). Niemniej jednak w bibliotece bialskiej znajdowało się już wówczas wiele cennych raritates, na które zwrócił uwagę ks. Referendarz (o czym szerzej w rozdziale dotyczącym wydawnictw). Gdybyśmy porównywali jednak bibliotekę samej Radziwiłłowej z zasobem jej brata Marszałka Pawła Karola Sanguszki ${ }^{47}$ ("Catalogus librorum (...) Pauli Caroli Sanguszko..." z 1737 roku) przekonalibyśmy się, że określana jako zbiór wcale nienajgorszy cała biblioteka lubartowska liczyła 1159 egzemplarzy (mniej niż tzw. podręczna Radziwiłłowej). Zresztą biblioteka Anny z Sanguszków Radziwiłłowej i starania o nią znane były dość powszechne. W jej korespondencji (co jest raczej rzadkością w listach) spotykamy stosunkowo często wzmianki o pożyczeniu książek, czy wręcz zamawianiu ich dla innych. Tu wspomnieć warto, że posyłała spisy ksiazzek i zamawiała je u wydawcy np. dla zięcia Michała Serwacego Wiśniowieckiego. ${ }^{48}$ "Posyłam zaś WXcey Mci Dobrodzieiowi Regestr Xiąg, które mi ida z Hollandyi; jeżeli co iest do upodobania Jego, tedy naznacz bo ja teraz jeno dla zabawy małe książki kazałam przysyłać. Posyłam przy tym y list z Hollandyi, w którym pisze, że konkluzye tey Xięgi, o którą WXca Mć piszesz, ieszcze nie wyszła, ale iak wyidzie nie omieszkam odesłać". Szkoda, że nie dowiemy się, jakie książki małego formatu zamówiła Radziwiłłowa i co chciał dokupić w Holandii Wiśniowiecki.

Czasem w korespondencji pojawi się ktoś niespodziewany, jak ów Józefat Hofman, Dominikanin piszący z Korczewa ${ }^{49}$ do Radziwiłłowej: "posyłam na powrót tę Xsiąszkę z kupersztychami młyńskimi do przekopiowania". Przykłady można mnożyć. Jej korespondencja z J.A.Załuskim została dostrzeżona. ${ }^{50}$ Polihistorowi - Janowi Fryderykowi Sapieżce ${ }^{51}$ posyłała "Theatre historique".

Z Janem Fryderykiem: Sapiehą wiąże ją także sporządzenie Genealogii Radziwiłłów (egzemplarze w Archiwum Radziwiłłowskim i Gabinecie 


\section{Rycin BN w Warszawie).}

Genealogia ta została opracowana ok. 1730 roku. ${ }^{52}$ J. F. Sapieha tak pisze w swoim liście do Radziwiłłowej. ${ }^{53}$ "Dziękując najuniżeniej WXMci za przysłanie Genealogy, z których iedną ImX Referendarzowi Koronnemu do Biblioteki dałem..." List ten sytuować można ok. 1730r., bowiem w korespondencji Sapiehy do J.A.Załuskiego ${ }^{\text {i4 }}$ odnajdujemy taką wiadomość: "Posyłam [chodzi tu o geneaologię] similiter temuż panu Sylwestrowi [Aleksandre Silvestre] Ogińskich, Radziwiłłów i Sanguszków, wszystkie Exactissime są zrobine, bo ostatnia wziąłem ex manuscripto samego książęcia Sanguszki, wojewody wołynskiego [Adam Aleks. Sanguszko zm. 1653] mając go sobie propria eius manu komunikowany in originali, od księżnej Jejmości Kanclerzynej lit. sub tempus prosperitatis". Z notatki tej wynika, że sztychowana genealogia Radziwiłłów z BN może być autorstwa Silvestre'a - choć równie dobrze może to być płyta przez innego twórcę przygotowana

Radziwiłłowa, jak już wspomniano, po 1741 roku rozpoczęła podział swego księgozbioru. Jak zaświadcza W. Nartowski ${ }^{35}$ W 1745 roku darowała "reformatorom 13 dzieł w 14 tomach, różnej treści obcych wydań. $\mathrm{Na}$ każdej z książek na stronie zewnętrznej oprawy lub na karcie tytułowej znajduje się adnotacja: "Hune librum pro bibliotheca conventus Albae Ducalis PP. Reform. anno 1743 do [..] obtulit Celsissima Principissa Anna Radziwiłłowa Fundatrix ac Benefatrix nostra Viscerosissima Cancellaria oretur pre es". Być może była to jedyna zanotowana darowizna na rzecz zgromadzen czy klasztorów.

Ciekawym zagadnieniem, które porusza Przypkowski ${ }^{\text {in }}$ jest brak exlibrisów Anny Radziwiłłowej, choć wiadomo, że książki były oznakowane numerami. Biblioteka Radziwiłłów była biblioteką ordynacką stąd też, jak sądzę, niemożliwe było oznakowanie książek przez żonę tylko.

\section{BIBLIOTEKA FRANCUSKA I PODRĘCZNA}

Data "1731" na "Katalogu biblioteki podręcznej Xżney Anny z Sanguszków Radziwiłłowej": ${ }^{57}$ dopisana już jest inną ręką - tą samą którą sporządzono napis "La Grande Bibliotheque". Natomiast słowa "Katalog bibl. podręcznej..." tą samą ręką która pisała podtytuł "Katalog biblioteki 
podręcznej bialskiej J.O.Ks. Radziwiłłów" w "Regestrze ksiąg francuskich 1731."158 Stąd też wynikła potrzeba skonfrontowania obydwu katalogów. Opisu bibliograficznego, ew. ustalenia autorstw itd. dokonano na podstawie dwu głównie bibliografii literatury francuskiej: Alexandre Cioranescu, Bibliographie de la Litterature Francaise du dixseptimem siecle, Paris 1965 1966, t. 1-3; Bibliographie de la literature francaise du dixhuitieme siecle, Paris 1969, t. 1-3 a także Barbiera E., Dictionnaire des cuvrages anonymes, Paris 1964 (reprint), t. 1-4. Dla potrzeb pracy zastosowano skróty: CBdelaLF i BarD.

W bibliotece francuskiej i podręcznej Anny z Sanguszków Radziwiłłowej znajdowały się co celniejsze płody ówczesnej kultury europejskiej. Rozumiem przez to dzieła nie tylko współczesnych ale i te, które z tradycji ówcześnie wybierano. Piszemy śmiało o kulturze europejskiej, bo w bibliotece odnajdujemy dzieła Anglików (Shaftesburry'ego, Locke'a czy też francuskie tłumaczenia "Spectatora"), najznakomitszych pisarzy hiszpanskich (de Quevedy, Ribandeiry, Alojzego Gonzagi), tłumaczenia Koranu itd. - jednakże poruszać się będziemy w obszarze kultury francuskiej - i tego co owa kultura $z$ myśli starożytnych $\mathrm{i}$ innych narodów przyswoiła światu.

Zbiór Radziwiłłowski wyróżniał się następującymi cechami: był dość sinie sprofilowany, zakupowano możliwie maksimum książek do rozbudowywanego działu. Sprofilowanie było podporzadkowane gustom mecenasa a $z$ drugiej strony wymaganiom bibloteki ordynackiej (stąd np. dział konstytucji polskich). Kupowano także bardzo chętnie wszelkie dzieła encyklopedyczne. Najobficiej reprezentowane sa działy: relogioznawczy, historyczny, geograficzny ( $z$ atlasami) literatury starożytnej i współczesnej (głównie powieść i dramat mniej poezja).

Bardzo ciekawa, dla opracowywanego przez nas zagadnienia mecenatu Radziwiłłowej jest sprawa odzwierciedlenia zainteresowań mecenatki w zbiorach biblioteki. I otóż, okazuje się, że posiadała ona dość duży zbiór pozycji "z poradami".

Szczególnie cenne działy to: XLIX i LVIII, gdzie znajdujemy takie pozycje jak: różnego rodzaju plany i widoki budowli, prace o unoszeniu wody i machinach (Nr B XLIX), prace poświęcone kartonom Le Bruna z francuskich manufaktur szpalerowych "Les quatres saisons" i "l,es quatre elements", portrety postaci w strojach "antiques", które mogły jej się przydać do portretów, emblematy, dewizy, "Livres pour peintres, graveurs, 
sculpteurs, orfevres, hologeurs, sculpteurs en platre", "Livre pour faire des dentelles, point et broderies" (które być może zawierały wzorniki haftu), "Un manuscript qui represent toutes sortes de dessein pour la broderie", "Plusieurs desseins pour la broderie", "Livre representant toutes sortes d'arbres, de fouillages, de fleurs, d'herbes et de parterres. Ce livre sert aussi dessiner et broder"; "Quatre livres representant toutes sortes de pieces chinoises et autres", "divers blasons", czy też przydatną dla zbiorów medalierskich wydaną w Paryżu 1693 "La science des medailles pour l'instruction de ceux qui s'appliquent a la connoissance des medailes antiques et modernes". W zbiorach tych także znalazły miejsce podręczniki ekonomiczne, jak np. dość znana pozycja Louis Ligera "Oeconomie générale ou ou nouvelle maison rustique" (Paryż 1701), czy też Audigera (Amsterdam 1700) "La maison reglée et l'art de diriger la maison d'un grand Seigneur et autres tant à la ville qu'a campagne et les devoirs de tous les officiers et autores domestiques".

W dziale XLVII, w którym znalazły się także poradniki postępowania z chorymi, poradniki kuchenne odnajdujemy i takie pozycje, które $\mathrm{z}$ pewnością zamówione były $\mathrm{z}$ myślą o udoskonaleniu pracy: przez Delormoisa napisana "Le teinturier parfait cu l'instruction nouvelle et générale pour la teinture des laines et manufactures de laine comme aussi pour les chapeaux" wydane w Lejdzie w 1708 roku (poz. 5). Wśród bardzo wielu zbiorów rycin, którymi chętnie posługiwała się Radzwiłłowa przy projektowaniu wzorów tkanin, szkła itd. wymienić można kilka, choćby: (dz. XLIX) "Portefeuille ou il'y a toutes sortes de peintures d'apprentisage", czy też "Autre porte feuille où l'on trouve toutes sortes de desseins, paysages, tailles douces et divers ornamens pour plafons, cintres, sur haisse, gallerieso, jetted'eaux et autre". Napotykamy także na przykłady wydań książek architektonicznych, Witruwiusza, Palladia itd. Do najcenniejszych, jak już wspomiano, partii tego zbioru należą teksty religioznawcze i teologiczne, które wymagałyby specjalistycznego opracowania. Niemniej jednak, daje się zauważyć, że Radziwiłłowa posiadała w swych zasobach przegląd ważniejszych doktryn i pism dotyczących historii kościołów, nie tylko katolickiego. Nie mniej miejsca zajmują pisma poświęcone sporom i polemikom (np. problemowi laski uświęcającej) czasów jej współczesnych. Znajdziemy tam twórczość kwietystów, molinistów, jezuitów, protestantów, ale co wydaje się niezwykle ciekawe - w bibliotece rzekomej zelantki Radziwiłłowej 
znajdujemy komplet pism jansenistycznych, choć brakuje "Myśli" Pascala (być może nie mogłam rozpoznać tytułu), P.Nicole, bracia Le Maitre, de Saci, F.Dauvilly, P.Davity, A.Arnauld, R.Arnauld d'Audilly, M. de Villeneuve, Sericourt, B.Pascal, Herment Godefroy, żeby wymienić nazwiska najwybitniejszych ludzi zwiazanych z Port-Royale. Musimy przy tym pamiętać, że w czsie, kiedy kupowano te dzieła - doktrynę potępiono. Zakupy sprawiają wrażenie celowej komplementarności - Radziwiłłowa miała najważniejsze dzieła tych twórców.

Zbiory literatury francuskiej uwzględniały wszystkie ważniejsze dzieła prozatorskie, rozprawy moralistyczne. Najsłabiej reprezentowany jest dział poezji a także dramatu. Właściwie poza tekstami dramatu włoskiego, na dziwnej zasadzie znajdujących miejsce w bibliotece, mamy tam do czynienia raczej tylko z dziełami zebranymi, np. Corneilla czy te Moliera. Zbiory poetów - to przeważnie dzieła starożytnych: Catullusa, Owidiusza, Horacego.

Dzieła historyczne i geograficzne należą przede wszystkim do opracowań niezwykle popularnej w tym czasie geografii i historii politycznej.

W literaturze historycznej zwraca uwagę obfitość pamiętników, opisów dworów itd. Ten typ ujęcia tematu przeważa także w sposobie opisu świata itd. W bibliotece podręcznej znalazły się także liczne dykcjonarze, czyli wydawnictwa typu encyklopedycznego - i to najznakomitsze.

Pominięto w katalogu wiele pozycji czasopiśmienniczych - choć, $\mathrm{z}$ całą pewnością gazety nadchodziły $\mathrm{i}$ to zarówno $\mathrm{z}$ Polski jak i z zagranicy. Księżna Kanclerzyna miała bowiem podpisany wieloletni kontrakt z Poczmistrzem Warszawskim, Benedyktem Kaliskim. ${ }^{59}$ Otrzymywał on 100 talarów bitych pensji za to, że "... powinien iestem J.O.X.Imci Radziwiłłowey a Miłościwej Dobrodzice posyłać Gazety wszelkie co poczta solita praxi, iako to: Francuska, Amszterdamską, leydeyska, la quinte [nieczytelne], Pruskie, Saskie, Wrocławskie, Berlińskie y Polskie tudziesz listy wszystkie". Rachunki płaciła dość wysokie - w 1728 r. - 606 zł, w 1731 r. -800 zł. W roku 1731 zamówiła: "Gazety Londyńskie, Amszterdamskie, d'Utrecht,Berlińskie i wrocławskie". Należy zwrócić uwagę, że posiadała francuskie wydanie "Spectatora".

Po bibliotece Radziwiłłowej widać zreszta jaką karierę zaczynają robić Anglicy - traktat J.Locke'a o edukacji w tłumaczeniu P.La Costy, był nawet pożyczony od ks. Hieronima F. lub Michała Kazimierza. ${ }^{60}$

Książnica księżnej Kanclerzyny ma raczej charakter "zachowawczy" - 
odzwierciedla gust kobiety żyjącej na przełomie wieków. Niemniej jednak obecność dzieł Lesage'a czy J.F.Bernarda "Ceremonies et coutumes de tous les peuples" świadczy o zainteresowaniu także literaturą współczesną.

Biblioteka Radziwiłłowej, mimo, iż była biblioteką prywatna, służyła innym - wystarczy wspomnieć o jej kontaktach czytelniczych z Załuskim, Wiśnjowieckimi, Sapiehą.

Dziś księgozbiór Anny Radziwiłłowej jest rozproszony, większa jego część zaginęła. Jednak na podstawie szczęśliwie zachowanych katalogów, możemy skonstatować, że był to jeden z lepszych zbiorów w Polsce, zawierajacy reprezentatywne dla myśli i kultury francuskiej pozycje.

Księżna Kanclerzyna była namiętną czytelniczką. W jej ciagłych podróżach towarzyszyły jej listy Deshomme'a, ${ }^{61}$ który posyłał jej książki: do Warszawy, na Litwę, Wiemy nawet, że tomy przewożono w specjalnie szytych worach. ${ }^{62}$

W świetle przytoczonych faktów widoczne jest, jak ważną była dla niej biblioteka i archiwum. Widoczne jest też, jak rozsądnie opiekowała się zbiorami Księżna Kanclerzyna.

Przypisy:

I.

F. Radziszewski: Wiadomosci historyczno-statystyczne..., Kraków 1875, s. 3 i s. 52

2.

Oczywiscie Annę z Sanguszków Radziwiłłową.

3.

Około 1741 roku, co potwierdza list do syna Michała Kazimierza

4.

Sądzić należy, co postaram sięudowodnić w dalszym ciagu pracy, że w Białej znajdowała się całą biblioteka ordynacka.

5 .

Już w czasach Anny Radziwiłłowej zbiorów było znacznie więcej. 
6.

Biblioteka po J. Flemingu, pierwszym mężu Tekli Radziwiłłówny zostałą przekazana przez nią cesją na brata Michała Kazimierza. AGAD, AR, dz. XI. 128 z 18.10.1745 r "Bibliotekę z Tomow, Xiąg różnych y osobliwszych manuskryptów złożoną na mnie Jure Saxonico po zeyściu z tego świata ImP Pana Karola Jakuba bionominis Graffa Fleminga syna mego, Xięgami y Manuskryptami nic z niey nie wyimuiąc ani excypuiąc ale i tak iak teraz iest w Warszawie ulokowana y osobliwszym Inwentarzem y Katalogiem opisana Jaśnie Oświeconemu Xiążenciu ImCi Michałowi Kazimierzowi (..) oddaie (...) y zapisuię." Regestr tej bibl. "Catalogi bibliothecae quandam Ilemingianae", AGAD, AR, Rękop. bibl karty inw. I - 3 .

\section{7.}

Pierwszym (ale, przecież byli wcześniejsi także) w takim ksztalcie powstałej biblioteki i archiwum bibliotekarzem był Affricanus Honorius de Goffaux (nie Aleksander!) kapitan garnizonu Słuckiego, komendant zamku bialskiego, dyrektor Archiwów Bialskich zamkowych w 1744 r. (AGAD, AR, dz. XXIII, t. 8). Swą funkcje pełnił przynajmniej od 1737 roku.

8.

AGAD, AR, rękopisy biblioteczne, karta inw. I - 7

9.

AGAD, AR, rękopisy bibloteczne, karta inw. I - 6.

10.

AGAD, AR, dz V, 76I63, list pisany z Nieświeża do Karola St. 02. 10.1713 roku.

11.

Zachowały się z wcześniejszych czasow dwa arcyciekawe katalogi Jeden rękopıśmienny znajduje się w Bibliotece Kórnickiej. Drugi, drukowany w Regiomontı 1673 "Catalogus librorum Boguslao Radziwiłł". Ow katalog opracowal i napisał przedmowę Martinus Silvester Grate, doktor teologii i bibliotekarz elektora, iest on zrobiony niezwykle porządnie - zawiera pelny tytuł, datę i miejsce wydania.

12.

N.K., t. 3, s. 314, poz. 7, Bibliotheca Fratrum Polonorum (7)

13.

N.K., t. 3, s. 153, "Przeróbkę tal polskiego oryginału wykonal Tomasz Treter. Edvycja z 1614 r. jest drugim wydaniem." 
14.

J. Radziszewska (Przedmowa do) M.Stryjkowski: () poczqukach wyurodach. dziclnosiciach (...) narodu litewskicgo, Warszawa 1878, s. 22

15.

N K, t. 2, s. 377, poz 10. Annalium Poloniae ab abitu Vladislai IV, Climacter primus, $\mathrm{Kr} .1683$ (...) Climacter secundus, Kr. 1688, brak dwu pozostałych.

16.

N.K., t. 3, s. 97, poz. 1

17

N.K., t. 3, s. 217, poz. 9, druk. w Krakowie

18.

N.K., 3, s. 103, poz. I

19

N.K., 3, s 125, poz. 44

20 .

N.K., t. 3, s. 303, poz 1

21.

N.K., t 3, s 284 , poz. 33

22. N.K., t. 3, s 98, poz. 2,3 (thumaczenta)

23.

NK, I s. 84, poz 2 (przekłady) druk Oliwa 1690

24

NK, I 2, s 511, poz. 2

25

N K, t 2, s 235 poz 2 (wydania zbiorowe)

26.

N.K., t. 3, s 444, poz. 2 podaje datę 1695 
27.

AGAD, AR, dz. XI 135 Dział między obydwu braci - Michała Kazimierza i Hieronima Floriana. Jednym z warunkow była koniecznośc sporządzania podwójnych kopii wszelkich dokumentow i dostarczania ich do Białej.

28.

AGAD, AR, dz. IV, 1. 723, pisany z Białej 2.10.1741 roku.

29.

AGAD, AR, dz V, 2996 pisany z Białej, 15,07.1737 r. Przedtem Deshomme w liście 2801.1737 informował księżna, że w bibliotece rozpoczał prace stolarz z Gdańska "menusie de Danzig"

30.

E.Lopacinski, Zamek w Bialej Podlaskiej, dane archiwalne. (w) Biuletyn Historii Sztuki, R. XIX (1957) nr 1, ss 27-48.

31.

AGAD, AR, dz. XVIII. c. 381, p 26

32.

AGAD, AR, dz XVII (3)

33.

AGAD, AR, dz XVU (7)

34

AGAD, AR, dz XVII (7)

35.

Pisal o tym E.Lopaciński, op. cit., s. 34.

36.

AGAD, AR, dz. V, t 641, list A.Goffaux z 21.12.1736r.

37.

Ibid., list z 10.01 1737 r. Trochę nie rozumiem końcówki listu. Czy Goffaux zbudowal jakiśs nowy młyn - czy też te inłyny należały do wystroju wnętrza w sali archiwum - która też w tyın czasie była kończona? Może A.Goffaux był projektantem o ile nie calości biblioteki - to może wystrij, wnętrz? 


\section{8.}

W latach dwudziestych; w kancelari zatrudniała, m. in. Marcina Zdorę - sekretarza.

AGAD, AR, dz. XI, 136, s. 177. To odsyłanie, o ktorym wspomina się w cytacie, też nie było nigdy zbyt prędkie.

40

AGAD, AR, dz V, 5262, korespondencja radcy dworu pruskiego G.H.Hoffmana z lat 1737 i 1738

41 .

Nie mogłam dojsć, na jakiej zasadzie ów Tera, Zera czy Fera nabył archiwa Radziwiłłów.

42.

AGAD, AR, dz V, t. 389, 15762 list Szmujly Ickowicza pisany 16.08.174l roku "O Archiwa do Dóbr Słuckich mam tu nieposlenie staranie ( . . ) byłem w sklepie zamkowym. ydzie są deponowane (...) skrzyń sztuk trzynaście ( ...) Sukcesor zaś Tera (Zera?) imieniem Fryderyk Wilhelm Adams wnuczkę pomienionego Fera (Tera, Zera) za sobą maiącą deklarował się mi wydać cokolek Papierów pod tą Kondycyą. żeby one nazad wróciły (...) Kupic je chcial rezydent Pruski za 28 000".

43.

AGAD, AR, dz. IV, I I158, b d., b m., ok 1741 r pisany do Michala Kazimierza lub Hieronima Floriana.

44 .

Ibid, 1. 366 pisany 01 03.1737 z Nalibok.

45

AGAD. AR, dz. IV (kopie), t. 13, nr 3 ok r. 1737, k. 256

46.

AGAD, AR, dz XXIII, t. 9, p. 3 Spis ksiązek zakupionych przez Brałłozora (Mateusza?): Atlas historique. Le Temple des Muses; Avanture de Telemaque; Bataille du Prince Eugene; Le Bombardier francaise: Corps diplomatique - complet 16 vol. Cerenonies des Peuples du Monde; Dictionnaire d'econonique du Chemel. Science des Ingenieurs par Belidor; Burnet: Histoire d'Angleterre; Quntynie: Instructions sur les jardins; Quinci Historia Militaria de Louis XIV; Historia de de Thou (XVI vol ): Puffendorf: Introduction a l'histoire, Le monde fou, Rollin. Historre anciene; Maniere d'enseigneur des bells lettres: Science de la Cour, Voyage de Benjamin Tudelle; Essay de Theodycee; Memoire sur le guerre; Histoire de Pologne de Parthenay ( 4 vol ): Locke: Education des Enfans: 
Reflexions morales, satiriques et comiques; Education des Filles; Cent nouvelle nouvelle par Madame de Gomez; Bibliotheque Francoise 20 vollumes; La Parfait connoissance des chevaux par Sonier; Le Paysan parvenu; Bibliotheque du Campagne; Vie de Mariane par Marivaux; Annomeus Historique, Histoire de George (5 vol.), gazette

47.

Archiwum m. Krakowa, Archiwum Sanguszków, sygn 531 .

48.

Biblioteka PAN, Kraków, Rkps 3599 listy Radziwiłłowej do Michała Serwacego Wisniowieckiego z 23.09.1740 pisany z. Białej i drugi 27.12.1740 także z Białej. W dopisku drugiego listu pisze: "Posylam paczek ksiag 4; iedna, co nalezy do tey, com tu dała WXMci ( . . ) ieszcze nie przyszły (te ksiazki do mnie) coś mi pisał (...) y tedy dość (...) pour le science)

49.

AGAD, AR, dz. V, 5264, list b.d z Korczewa.

50.

Korespondencja do J A.Załuskiego, Wroclaw 1967, s. 24, I. 56

51.

AGAD, AR, dz IV, 1. 13, nr 1, list z 22.05.1739 r. W liscie tym Radziwiłłowa prosi o zwrot pożyczonej ksiązki

52.

AGAD, AR, dz XXVI, 239, Potwierdza to także chyba "Inwentarz skarbców Górnych..." z $05.01 .1733 \mathrm{r}$ gdzie zapisane

"egealogie papierowe".

"enelogy Fimilijey Radziwil. 34

enelogy Fimilijey Radziwił iedna stara I."

53.

AGAD, AR, dz V, t. 327, 13831, list b.d, b. m.

54.

Korespondencja do J.A.Zaluskiego,op. cit., s. 63, I. 108, pisany z Kodnia 10.06.1731 r.

55 .

W. Nartowski. Karty z przeszłości Białej..., Biała 1926, s. 42.

56.

T. Przypkowski, Z dziejów kultury książi w Polsce. Dawne Biblioteki Radziwiłłów i ich 
księgoznaki. Kraków 1942. Maszynopis BUJ, Aks. 369/81

57.

AGAD, AR, dz Rękopisy bibl., karta inwent. nr I-12.

58.

AGAD, AR, dz Rękopisy bibl., karta inwent. nr I-10.

59.

AGAD, AR, dz. XXIII, t. 8, plik. II Umowy z lat 1728-1731. Sądzę, że w innych latach zawierała podobne kontrakty.

60.

AGAD, AR, dz. V, 13445, list Antoniny Rudzienskiej: "Pamiętna będąc rozkazuw WXMCi Dobrodzieia naprzud książkę de L'education des Enfans par Mr Loc [Locke] zaraz powróciwszy z Białej miaiąc okazyo odsyłam do Białey".

61.

AGAD, AR, dz V, 2996 by wymienić jeden $z$ nich z 14.06.1737. "I'anvojé a V.A. la Livre pour Grange et 13 livre pour le quois et 6 livre pour Palsernie. Le rest de le Livre I l'anveray par premier occassion comme ausi les chappeaux et Bas que ie doit Recevoir de Varsowie".

62 .

AGAD, AR, dz. XXVI, 238 "Rozchód skarbcu dolnego przez Burgiele." I1.10.1732 31.01.1733: "płutno zgrzebne na wur do ksiązek posłano do Litwy dla J.O X.M." 